This is an Accepted Manuscript of an article published by Taylor \& Francis in Journal of Interprofessional Care on 13 December 2017, available online: http://www.tandfonline.com/10.1080/13561820.2017.1408576 
Examining the nature of interprofessional practice: An initial framework validation and creation of the InterProfessional Activity Classification Tool (InterPACT)

\author{
Andreas Xyrichis ${ }^{1 *}$, Scott Reeves ${ }^{2}$, Merrick Zwarenstein ${ }^{3}$ \\ ${ }^{1}$ Florence Nightingale Faculty of Nursing, Midwifery \& Pallia- \\ tive Care, King's College London University, UK \\ ${ }^{2}$ Faculty of Health, Social Care and Education, Kingston Univer- \\ sity \& St George's, University of London, UK \\ ${ }^{3}$ Department of Family Medicine, Schulich School of Medicine \& \\ Dentistry, Western University, London ON, Canada \\ *Corresponding author \\ E-mail: andreas.xyrichisekcl.ac.uk (AX)
}




\title{
Examining the nature of interprofessional practice: An initial framework validation and creation of the Inter- Professional Activity Classification Tool (InterPACT)
}

\begin{abstract}
The practice of, and research on interprofessional working in healthcare, commonly referred to as teamwork, has been growing rapidly. This has attracted international policy support flowing from the growing belief that patient safety and quality of care can only be achieved through the collective effort of the multiple professionals caring for a given patient. Despite the increasing policy support, the evidence for effectiveness lags behind: while there are supporting analytic epidemiological studies, few reliable intervention studies have been published and so we have yet to confirm a causal link. We argue that this lag in evidence development may be because interprofessional terms (e.g. teamwork, collaboration) remain conceptually unclear, with no common terminology or definitions, making it difficult to distinguish interventions from each other. In this paper, we examine published studies from the last decade in order to elicit current usage of terms related to interprofessional working; and, in so doing, undertake an initial empirical validation of an existing conceptual framework by mapping its four categories (teamwork, collaboration, coordination, and networking) against the descriptions of interprofessional interventions in the included studies. We searched Medline and Embase for papers describing interprofessional interventions using a standard approach. We independently screened papers and classified these under set categories following a thematic approach. Disagreements were resolved through consensus. Twenty papers met our inclusion criteria. Identified interprofessional work
\end{abstract}


interventions fall into a range, from looser to tighter links between members. Definitions are inconsistently and inadequately applied. We found the framework to be a helpful and practical tool for classifying such interventions more consistently. Our analysis enabled us to scrutinise the original dimensions of the framework, confirm their usefulness and consistency, and reveal new subcategories. We propose a slightly revised typology and a classification tool (InterPACT) for future validation, with four mutually exclusive categories: teamwork, collaboration, coordination, and networking. Consistent use, further examination and refinement of the new typology and tool may lead to greater clarity in definition and design of interventions. This should support the development of a reliable and coherent evidence base on interventions to promote interprofessional working in health and social care.

Key words: Interprofessional practice, collaboration, teamwork, coordination, networking, validation, classification tool

\section{Introduction}

Poor communication and cooperation between different professionals, commonly referred to as lack of teamwork, has long been implicated in negative patient outcomes and an increase in clinical errors (e.g. Joint Commission, 2008; Khon, Corrigan, \& Donaldson, 2001; Page, 2004). In the context of international scarcity and maldistribution of healthcare resources, successful interprofessional work activity has been championed as a means of reducing waste 
and avoiding duplication of effort; and in this way injecting efficiency in health systems (Carter, 2016). However, interprofessional working in health and social care has been uncritically adopted as the solution to a wide range of problems, with little attention given to developing conceptual clarity over what exactly this way of working might represent (Xyrichis \& Ream, 2008). As Barr (2010) warned, interprofessional working "is in danger of being reified as a self-evident virtue in need of neither justification nor critical review" (p.11). Indeed, even its definition remains unclear. In this paper we undertake a critical review to examine published studies from the last decade in order to elicit current usage of terms related to interprofessional working; and, in so doing, undertake an initial step in empirically validating a previously developed conceptual framework (Reeves, Lewin, Espin, \& Zwarenstein, 2010) by examining its categories alongside the descriptions of interprofessional interventions in the included studies.

\section{Background}

It is agreed that interprofessional working is a heterogeneous construct and as such it can be conceptualised in different ways (e.g. Dow et al., 2017; Manser, 2009; Salas, Cooke, \& Rosen, 2008). The setting in which this work is carried out, the number and types of profession- 
als involved and the kind of healthcare problems it aims to address can all influence the way in which it is perceived and defined. In the early 1990s Leathard (1994) examined the wide range of terms employed in the literature and found a 'terminological quagmire' - a situation that had not changed nearly a decade later when she subsequently published on this issue (Leathard, 2003). Other more recent reviews agree (Dietz et al., 2014; Paradis et al., 2014; Reeves et al., 2011). Dietz et al.(2014) specifically pointed out that conceptual and definitional clarity are needed to underpin empirical evaluation of interventions and synthesis of results across research studies.

There are very few high-quality intervention studies demonstrating that interprofessional work activities can have a meaningful impact on health or healthcare outcomes (Reeves, Pelone, Harrison, Goldman, \& Zwarenstein, 2017); and the wide attention drawn to these few studies has contributed to the terminological confusion. A popular intervention in North America, TeamSteps ${ }^{\circledR}$, has been endorsed by the Agency for Healthcare Research and Quality (AHRQ) and widely regarded as an evidence-based intervention aimed at improving 'teamwork' skills among healthcare professionals, using a combination of training materials. ${ }^{1}$ Similarly, in the UK, the MDT-FIT (Multidisci- 
plinary Team Feedback for Improving Teamworking) has been endorsed by NHS Improving Quality (NHSIQ) as an evidencebased tool specific to cancer care teams to self-assess and receive feedback on how their team performs. ${ }^{2}$ While these tools have shown some promise, neither has been tested in high-quality intervention studies, and nor do they specify the kind of interprofessional work they are designed to address. Instead, these follow the literature in conflating all kinds of interprofessional work activities into 'teamwork'.

Unless there is greater clarity in the field about the different kinds of interprofessional work, progress in identifying which works better and under which circumstances will continue to be slow and unreliable. In this paper we respond to this problem with a critical review of recently published studies, examining the empirical validity and currency of our existing theoretical framework (Reeves et al., 2010); and propose a modification and tool, the InterProfessional Activity Classification Tool (InterPACT), to help inform and strengthen the design of future research as well the dissemination and translation of such work.

Conceptual framework 
In an attempt to offer a framework that could help improve conceptual clarity in this field two of us, with colleagues, undertook a critical assessment of the literature on interprofessional working from a variety of clinical settings and in different national contexts (Reeves et al., 2010). In that work, interprofessional practice was viewed as an activity which varies along six key dimensions of the relationships between those working together - clarity of: (1) goals; (2) roles and responsibilities; and degree of (3) shared identity, (4) commitment, (5) interdependence and (6) integration between clinical tasks. Drawing from an analysis of the literature a typology was proposed which introduced a 'contingency approach' to interprofessional work. Such an approach regarded qualitatively different forms of interprofessional work, particular patient needs and practice demands might be best matched to one of four kinds of activity: teamwork, collaboration, coordination or networking. These activities are described in Table 1.

\section{INSERT TABLE 1 ABOUT HERE}

These four types were also illustrated as nested circles, but not to imply Venn diagram-like overlap. Rather, they were viewed as four types of increasingly 'tight' forms of interprofessional practice, moving from outermost to innermost circles (Figure 1). 
While the merit of this classification is intuitive to many working in this field, it represents a view of the different strands of interprofessional work that the field should explore, not what it currently does. For example, the use of the terms 'team' and 'teamwork' are commonplace in the literature, but these are often used to describe very different types of interprofessional work. The 2010 typology was therefore tentative in nature and needed to go through a process of empirical validation to begin to establish its robustness for use in clinical practice.

\section{Methods}

We undertook a critical review (Jesson \& Bissell, 2006; Jesson \& Lacey, 2006) of recently published literature on interprofessional interventions. The objectives were to: (1) explore consistency and convergence of interprofessional definitions used in the literature; (2) undertake an initial step towards empirically validating the Reeves et al. (2010) framework; and (3) modify the framework in response to the findings from the review in order to inform future work. The three authors held regular meetings throughout the process, with key decisions recorded on a decision audit trail.

Data sources 
Guided by the previous interprofessional typology, we undertook a series of searches for empirical work in the Medline and Embase databases in August 2015 using the terms shown in Table 2. In order to exclude non-empirical work, a methodological filter was applied drawing from existing guidance (SIGN, 2015). Limiting to 10 years ensured currency of retrieved papers.

\section{TABLE 2 ABOUT HERE}

Inclusion criteria

To gain insight to the nature of current research in this field, the 50 most recent interprofessional intervention studies retrieved from the search for each category (teamwork, collaboration, coordination, networking) were read and assessed for eligibility by the first author. To be considered, papers had to be reporting: (i) on an empirical study; (ii) of an interprofessional intervention/activity; which (iii) was explained in sufficient depth to enable an assessment of its content (kind and number of professionals involved, e.g. doctors, nurses, pharmacists) and form (purpose and ways of working, e.g. through regular or ad hoc meetings, face to face or remote working). Papers that provisionally met the inclusion criteria were presented for a team discussion. 
Analysis

The analysis was guided by the Reeves et al. (2010) framework and its associated classifications. This process consisted of four main stages. First, we each independently read each paper, paying particular attention to the description of the interprofessional activity reported on. We also noted how the authors chose to describe their way of working and considered this alongside the categories of the previously developed framework. Then, each author attempted to classify each paper under one the four categories of interprofessional teamwork, collaboration, coordination and networking; noting papers for which a decision was difficult or that did not seem to fit the existing schema. Finally, we held regular meetings to review our separate analysis and classifications, examining areas of convergence and disagreement. Through a process of consensus, we agreed on our final classification and recorded our decisions in an audit trail.

\section{Results}

Overview of search results

The volume of literature identified through the search even though this was designed with specificity rather than sensitivity in mind - demonstrates increasing research activity around interprofessional working in 
healthcare. While this was not meant to be a bibliometric study, it is worth noting the disparity of results between the searches for the four kinds of interprofessional work activity. Specifically, the search for collaboration generated the most results ( $n=1639,54 \%)$, followed by teamwork ( $n=929,31 \%)$, coordination $(n=286,10 \%)$ and networking ( $n=157,5 \%)$. These results suggest that the terms most widely associated with interprofessional work are collaboration and teamwork, which is not surprising given the policy attention and positive management rhetoric around these two ideas. Following screening of papers, application of the inclusion criteria noted above and discussion between the authors 20 papers met the inclusion criteria for in-depth analysis (Figure 2). FIGURE 2 ABOUT HERE

\section{Summary of papers}

The included papers (Table 4) reported studies undertaken over eight countries: the USA $(n=6)$ (Auerbach et al., 2011; Bekelman et al., 2015; Gausvik, Lautar, Miller, Pallerla, \& Schlaudecker, 2015; Gums et al., 2014; O'Leary et al., 2011; Saint et al., 2013), Canada ( $n=5)$ (Bissonnette, Woodend, Davies, Stacey, \& Knoll, 2013; Dhalla et al., 2014; Markle-Reid et al., 2014; Moore et al., 2012; Rice et al., 2010), Sweden (n=2) (Berglund, Hasson, Kjellgren, \& Wilhelmson, 2015; Muntlin Athlin, 
von Thiele Schwarz, \& Farrohknia, 2013), Denmark (n=2) (Bunkenborg, Samuelson, Poulsen, Ladelund, \& Akeson, 2014; Lisby et al., 2009), The Netherlands (n=2) (Munneke et al., 2010; Van Veen-Berkx, Bitter, Kazemier, Scheffer, \& Gooszen, 2015), Australia (n=1) (Black et al., 2013), Belgium ( $\mathrm{n}=1$ ) (Deneckere et al., 2013) and Thailand ( $\mathrm{n}=1$ ) (Korbkitjaroen et al., 2011).

Most of the studies followed a quantitative design (n=18), either experimental, quasi-experimental or observational. Two studies utilised qualitative approaches (Moore et al., 2012; Rice et al., 2010). ${ }^{3}$ Interprofessional working interventions were introduced in a range of healthcare settings, such as general inpatient wards, emergency departments, operating rooms, community and primary care settings; and with people suffering from both acute and chronic health issues such as Parkinson's disease.

Overview of interventions

The 20 papers reported on interventions of different form and content, involving an array of health professionals. Notable examples include: Munneke et al. (2010) interprofessional network of over 2,700 physiotherapists, physicians and other health professionals in the Netherlands through which they worked to improve communication, information and knowledge exchange; Rice et al. (2010) col- 
laborative intervention at a medical ward involving nurses, physicians, physiotherapists, dieticians, pharmacists and others through which they sought to improve the quality of interprofessional interactions, communication and patient care decision making; Berglund et al. (2015) nurse-led coordination of geriatric assessment, discharge, care planning and home visits alongside a social worker, physiotherapist and occupational therapist; and, Moore et al. (2012) family practice that involved a team of professionals jointly assessing, planning and evaluating team care plans for the practice patients through regular team meetings.

The level of detail provided in the different studies varied, as did the terminology used to describe their interventions. Some terms used were 'cross-functional teams' (Van Veen-Berkx et al., 2015), 'collaborative management' (Gums et al., 2014), 'team-based approach' (Black et al., 2013), 'hospitalist-based medicine team' (Saint et al., 2013), 'collaborative care approach' (Bissonnette et al., 2013) or 'collaborative care intervention' (Bekelman et al., 2015) among others. Many of the studies, while providing a description of the key components of their intervention, did not consider a standardised terminology nor did they attempt to explic- 
itly classify it as a particular kind of interprofessional work activity.

Using the 2010 framework we sought to standardise the descriptions of these interventions and classify them under the four categories of teamwork, collaboration, coordination and networking; remaining mindful of the distinguishing dimensions among these categories. For example, Deneckere et al. (2013) described the development of care pathways as an "interprofessional teamwork" intervention; but this lacked clear evidence of a shared team identity or responsibility (see Table 1 ). It was therefore reclassified as interprofessional collaboration. Similarly, Bunkenborg et al. (2014) referred to their intervention as "interprofessional collaboration" even though this lacked shared accountability between individuals and clear evidence of interdependence. Instead, it centred on a physician-led development of an assessment and treatment algorithm for nurses to use, report back and discuss in daily meetings. In this sense, the intervention was reclassified as interprofessional coordination.

As a result of this process, the included studies were classified as either: interprofessional teamwork $(n=4)$; interprofessional collaboration ( $\mathrm{n}=8)$; interprofessional coordination $(n=7)$ or interprofessional networking $(n=1)$. 
Table 3 presents a summary of how the interventions were described in the papers and how these were classified after application of the framework (Reeves et al., 2010).

\section{INSERT TABLE 3 ABOUT HERE}

Types of interprofessional work

To date, discussions around interprofessional ways of working have failed to adequately distinguish between the different kinds of such work. In this paper we sought to undertake an initial step towards the empirical validation of the previously developed framework (Reeves et al., 2010) by using it to reclassify interprofessional work interventions reported in recent literature; and found this framework to be a helpful and practical tool to use for this purpose. The original framework visualised the different kinds of interprofessional work within an interrelated and embedded schema (Figure 1). Based on the work undertaken for the current paper we propose that these can be seen as a continum of looser to tighter team links. Interprofessional teamwork and network, as the two extreme ends of the continuum, are easy to discern; with interprofessional collaboration and coordination as intermediate categories, each of which contain sub-categories (Table 4).

Given the limited number of cases, we propose the below revisions to the previously developed framework as ex- 
ploratory. It should also be noted that it is conceivable for the proposed categories and sub-categories to coexist around a patient or professional simultaneously. This opens up the possibility of professionals being, for example, collaborative at one care juncture and coordinative at another.

Interprofessional collaboration. Upon closer inspection of the collaboration category, two studies initially classified under this seemed qualitatively different: Bekelman et al. (2015) and Gums et al.(2014). Firstly, while Bekelman et al. provided a description of their intervention (heart failure disease management) that seemed to naturally fall within the collaboration category, the outcome of their work relied on others (the primary physician) actually taking their recommendations on board. Consequently, if the physician chose to ignore the team's recommendations then the work of the team would have no tangible outcome and seem non-existent. In this sense, the work of the team was more consultative in nature. Therefore, while we classified this intervention within the collaboration category we also agreed this formed a sub-category in itself, which we term 'consultative collaboration'. Secondly, the intervention reported by Gums et al. on asthma management incorporated the features of the collaboration category but it essentially consisted 
of two professions - a pharmacist and a physician. In many ways, portraying a dyad as an interprofessional team is conceptually complex and out of sync with normal use of the term. Therefore, we agreed this consisted another sub-category which we term as 'collaborative partnership'

Interprofessional coordination. Within the interprofessional coordination category there were three reports that were different enough to warrant further consideration: Muntlin Athlin et al. (2013), Saint et al.(2013) and Lisby et al.(2009). Firstly, while Muntlin Athlin et al. gave a fitting example of a coordinated working practice in an emergency department, the onus of the work rested on the lead physician who then delegated and oversaw the work of other clinicians. While this fits our understanding of coordinated work we concluded it consisted a distinct sub-category termed 'delegative coordination'. Secondly, the intervention described by saint et al. seemed to fall into two tiers whereby the outcomes of what appeared to be a collaborative team were then implemented and followed through by a clinical care coordinator -whose work was predominantly that of coordination. As another distinct kind of practice, falling in between collaboration and coordination, we classify it as a subcategory which we term 'coordinated collaboration'. 
Thirdly, Lisby et al. in their study of pharmacist and pharmacologist coordination of physicians' prescriptions describe the provision of what appeared to be a consultation service. Therefore, as a different form of coordination, it was assigned to another sub-category termed 'consultative coordination'.

TABLE 4 ABOUT HERE

Dimensions of interprofessional work In addition to revisiting the different types of interprofessional work, our analysis also enabled us to scrutinise the original definitions of the 2010 framework. Those definitions proposed a set of dimensions that distinguish between the different kinds of interprofessional working: (1) shared commitment; (2) shared team identity; (3) clear goals; (4) clear team roles and responsibilities; (5) interdependence between team members; and (6) integration between work practices. In our original framework the nature of the task was a further dimension of the type of interprofessional work, in terms of predictability, urgency and complexity of the task. Based on our current analysis we propose a series of updates, as outlined below.

We found all of these dimensions helpful in conceptualising interprofessional interventions, except those related to the task (predictability, urgency, and complexity). We 
propose that the character of the task should not itself lead to the classification of the type of interprofessional work, or the intervention to encourage it. And indeed, as we classified the interventions in these studies, we found that the nature of the tasks in different studies differed, but these task differences were not associated with specific types of interprofessional interventions. Different kinds of interprofessional work can thus address similar tasks, some of which might be more or less predictable, urgent or complex, and the same intervention can be used to encourage interprofessional work for tasks which vary in their predictability, urgency and complexity. For example, the study by o' Leary et al. (2010) reported on the introduction of interprofessional weekly rounds utilising a structured communication tool that enabled joint patient care discussion and planning. In this example, the acuity and complexity of the patient condition would dictate the nature of the team task, which could vary; if the patient was acutely unwell or in deterioration it could be highly urgent, complex and in many ways unpredictable. But across any type of patient and task, the intervention was constant. Therefore, we argue that as the nature of healthcare service delivery becomes increasingly complex, and as health and illness patterns continue to change in unpredictable ways, each kind of interprofessional activity will need 
to accommodate different tasks with a range of predictability, complexity and urgency. The association between the combination of such task characteristics and kind of interprofessional activity can be the subject of further examination in future work.

Although we consider the other dimensions helpful to retain, we propose these are more clearly defined to introduce further conceptual clarity to the framework. To this end, we propose the following:

- By team commitment, we refer to the psychological attachment that healthcare professionals feel toward their team (based on Pearce \& Herbik, 2004).

- With team identity, we mean the collection of meanings attached to their team by healthcare professionals (based on Miscenko \& Day, 2016).

- Team goals, refer to the explicit articulation of the purpose and ambition of the interprofessional team (based on Katzenbach \& Smith, 1993).

- With team roles and responsibilities, we refer to the differentiation of healthcare professional jurisdiction among the interprofessional team members. Based on Abbott (1988), a jurisdiction refers to the link between a profession and its work; and signifies the ex- 
tent to which a profession holds authority over a bundle of work tasks.

- Team interdependence, is the extent to which the outcome of an interprofessional interaction depends on the decisions and choices of all team members (based on Kelley \& Thibaut, 1978).

- By integration of work practices, we refer to the alignment of professional practice towards a whole product to which healthcare professionals contribute. Here, product is used to refer to any intended output of an interprofessional healthcare team whether that be improved safety, quality, efficiency or care planning.

We propose the above definitions as descriptors to guide researchers and clinicians in distinguishing, classifying and standardising the use and kinds of interprofessional work interventions/ activities; and, offer the InterProfessional Activity Classification Tool (InterPACT) to assist in this process, proposed usage of which is explained next.

\section{Classification tool}

Based on the above analysis, we propose the InterPACT (Table 5) to help with the empirical application of the framework; and assist in making decisions about classifying types of interporfessional work, and interventions to 
promote it. In this classification tool, each kind of interprofessional work is presented alongside the six dimensions, indicating the level $(\oplus \oplus \oplus \oplus)$ of intensity expected.

TABLE 5 ABOUT HERE

We propose this tool not as a finished product, but as an initial conceptual basis from which research, practice and educational advancements in our field can be made. We offer InterPACT as a guide to help with the application of the framework in real life situations; and to invite more critical reflection on the work of existing and new interprofessional initiatives.

How to use InterPACT. In the first instance, we invite colleagues to use our classification tool as a diagnostic, self-assessment exercise, introduced as part of a collegial discussion. We encourage colleagues to collectively reflect on each of the six dimensions (shared commitment; shared team identity; clear goals; clear team roles and responsibilities; interdependence between team members; and integration between work practices) and pragmatically note, in the context of their particular setting, the extent to which each dimension characterises their way of working. 
Then, as a second step, colleagues should discuss the result of their self-assessment alongside the four main types of interprofessional activity (teamwork, collaboration, coordination, and networking) and reflect on which one currently represents their way of working; and which one they may want to develop towards. We believe that there are likely to be cost and organisational consequences arising from this choice, and we emphasise that no kind of interprofessional work activity in the classification tool is intrinsically superior to any other. Rather, the type of interprofessional work should be matched to patient needs and the organization of care delivery dynamically. We advise against aspiring towards a particular kind of interprofessional working arrangement on the basis of perceived hubris or dysfunction. Instead, we encourage colleagues employ the 'contingency approach' (Reeves et al., 2010) in order to consider the actual needs of their patients (where possible, including patients in this discussion) and the demands and constraints on their practice, in order to collectively decide which kind of interprofessional work pattern would be the best match.

Once the kind of interprofessional work that best characterises an activity is decided, a third step should involve colleagues considering the level of dosage/ inten- 
sity needed across the six dimensions and reflect on ways of injecting this, if needed, to their working practices. We suggest this diagnostic, self-assessment exercise is undertaken periodically to check progress and adjust prescription, in terms of dosage for each dimension, accordingly.

\section{Discussion}

The notion of improving the delivery of healthcare services through interprofessional working has been around for many years, as have attempts to improve the quality of such ways of working (Khon et al., 2001; Reeves et al., 2017). Having previously scoped the literature in the area (Reeves et al., 2010), we revisited the issue in this paper. While research in this way of working has significantly increased, the interprofessional field remains poorly conceptualised in many empirical studies; with an on-going terminological confusion about different kinds of interprofessional work activity such as collaboration, teamwork and coordination. This appears to be the key reason hindering and delaying our progress in understanding which kind of activity works better in which settings. In the 20 studies we included in the current analysis we were able to: confirm the ongoing lack of conceptual clarity and inconsistent terminology used in the field; establish the existence of four kinds of in- 
terprofessional work we previously hypothesised; identify five additional sub-categories; and propose InterPACT for use in the design and evaluation of future interprofessional research and practice.

We draw attention to InterPACT in particular (Table 5), which can be developed to act as a much-needed diagnostic, self-assessment instrument for use by both teams and evaluators. Even though there are existing selfassessment tools specifically for teamwork, these do not meet their potential because they fall short of differentiating between the different kinds of interprofessional work and instead conflate them all as teamwork. Interprofessional teams and evaluators can adopt, examine and if needed adapt InterPACT to help them reflect on the nature of their existing setup, consider which kinds of interprofessional work activity they want to pursue and develop interventions accordingly. In this way, research in this field can move from conceptual to empirical categorisation, using our classification as a tool, not to measure the quality, but the relative dose of the different dimensions of interprofessional work. In addition to its practical application, InterPACT also has implications for theory development. Despite past attempts at developing conceptual maps and theoretical models in this field, there remain few substantive theories to pave the 
way forward; owing to a lack of understanding and confusion around the kinds and dimensions of interprofessional work. We invite theorists to use our revised typology and classification tool to help develop theoretical literature on interprofessional practice.

Our results and conclusions should be considered in the context of the limitations of this work. Firstly, as a critical review this work did not aim to identify and summarise all available interprofessional interventions in publication; rather, our focus was the application of an existing classification framework on a selected group of studies of interprofessional work, in order to examine its practicability and as an initial step towards exploring the empirical validation of its use. Secondly, our time and funding constraints meant this review was necessarily selective, privileging currency and quality of each study over quantity of papers; we acknowledge that some deviant cases or further examples of sub-categories have been missed.

As a conceptual analysis, this paper represents an initial attempt at providing the conceptual building blocks to advance the development of a programme of research in this field. In this sense, the utility and validity of 
our modified framework and classification tool will be ascertained through future research.

\section{Concluding comments}

Based on the work undertaken in the current paper, we both endorse and update a previous framework (Reeves et al., 2010), as a practical tool for standardising and communicating practice and research around interprofessional work. We clarify the four main kinds of interprofessional work activity, propose a modified typology to account for additional sub-categories we identified, define the six dimensions of interprofessional work, and present InterPACT: a tool to assist in making decisions about designing, classifying and evaluating interprofessional activities and interventions.

We challenge future research to use, and in so doing examine and refine, the proposed typology and classification tool to clearly position interprofessional interventions under one of the four main categories of teamwork, collaboration, coordination, and networking; and, where appropriate, under a sub-category. We recommend the development of programmes of research that study each of these categories at greater depth in order to contribute to their further development and refinement. In addition, the six dimensions of the framework could also be exam- 
ined in future research by, for example, seeking answers to questions such as: what tools could be used to measure the six dimensions proposed; can different combinations of these dimensions lead to different kinds of interprofessional activity; and do the proposed dimensions track independently of each other?

Consistent application of the proposed classification tool and, by extension, use of the four main categories will lead to greater clarity in the field and enable the built up of a more reliable and coherent evidence base on interprofessional working in healthcare. Through this paper, we have made a start in that direction and invite others to build on this work in order to drive practical, educational and theoretical advancements in the interprofessional field internationally.

\section{Notes}

1. For more information about Teamsteps see: https://www.ahrq.gov/teamstepps/index.html

2. For more information about MDT-FIT see: http://www.nhsiq.nhs.uk/improvement-programmes/long-termconditions-and-integrated-care/mdt-fit-tool.aspx

3. We were surprised by the limited number of qualitative studies that reported on the implementation or evaluation of a clear interprofessional activity. This suggests more work needs to be done to encourage use, as well as better reporting, of qualitative studies in this line of work.

\section{Declaration of interest}


The authors report no conflicts of interest. The authors alone are responsible for the writing and content of this article.

\section{References}

Abbott, A. (1988). The system of professions. An Essay on the division of expert labor. Chicago: University of Chicago Press.

Agency for Healthcare Research and Quality. [online] Retrieved from

http://www.ahrq.gov/professionals/education/curriculumtools/teamstepps/index.html

Auerbach, A. D., Sehgal, N. L., Blegen, M. A., Maselli, J., Alldredge, B. K., Vittinghoff, E., \& Wachter, R. M. (2011). Effects of a multicentre teamwork and communication programme on patient outcomes: results from the Triad for Optimal Patient Safety (TOPS) project. BMJ Quality \& Safety, 21(2), 118-126. doi:10.1136/bmjqs-2011000311

Barr, H. (2010). Forward. In Reeves, S., Lewin, S., Espin, S., \& Zwarenstein, M. (2010). Interprofessional teamwork for health and social care. Sussex: WileyBlackwell..

Bekelman, D. B., Plomondon, M. E., Carey, E. P., Sullivan, M. D., Nelson, K. M., Hattler, B., . . Rumsfeld, J. S. (2015). Primary results of the PatientCentered Disease Management (PCDM) for heart failure study a randomized clinical trial. JAMA Internal Medicine, 175(5), 725-732.

doi:10.1001/jamainternmed.2015.0315

Berglund, H., Hasson, H., Kjellgren, K., \& Wilhelmson, K. (2015). Effects of a continuum of care intervention on frail older persons' life satisfaction: a randomized controlled study. Journal of Clinical Nursing, 24(7-8), 1079-1090. doi:10.1111/jocn.12699

Bissonnette, J., Woodend, K., Davies, B., Stacey, D., \& Knoll, G. A. (2013). Evaluation of a collaborative chronic care approach to improve outcomes in kidney transplant recipients. Clinical Transplantation, 27(2), 232-238. doi:10.1111/ctr.12068 
Black, D. A., Taggart, J., Jayasinghe, U. W., Proudfoot, J., Crookes, P., Beilby, J., . . Teamwork Research, T. (2013). The Teamwork Study: enhancing the role of non-GP staff in chronic disease management in general practice. Australian Journal of Primary Health, 19(3), 184-189. doi:10.1071/PY11071

Bunkenborg, G., Samuelson, K., Poulsen, I., Ladelund, S., \& Akeson, J. (2014). Lower incidence of unexpected inhospital death after interprofessional implementation of a bedside track-and-trigger system. Resuscitation, 85(3), 424-430. doi:10.1016/j.resuscitation.2013.11.023

Carter, P. (2016). Operational productivity and performance in English NHS acute hospitals: Unwarranted variations. An independent report for the Department of Health by Lord Carter of Coles. London: Department of Health.

Deneckere, S., Euwema, M., Lodewijckx, C., Panella, M., Mutsvari, T., Sermeus, W., \& Vanhaecht, K. (2013). Better Interprofessional Teamwork, Higher Level of Organized Care, and Lower Risk of Burnout in Acute Health Care Teams Using Care Pathways A Cluster Randomized Controlled Trial. Medical Care, 51(1), 99-107.

doi:10.1097/MLR.0b013e3182763312

Dhalla, I. A., O'Brien, T., Morra, D., Thorpe, K. E., Wong, B. M., Mehta, R., . . Laupacis, A. (2014). Effect of a postdischarge virtual ward on readmission or death for high-risk patients: a randomized clinical trial. Journal of the Americal Medical Association, 312(13), 1305-1312. doi:10.1001/jama.2014.11492

Dietz, A. S., Pronovost, P. J., Mendez-Tellez, P. A., Wyskiel, R., Marsteller, J. A., Thompson, D. A., \& Rosen, M. A. (2014). A systematic review of teamwork in the intensive care unit: What do we know about teamwork, team tasks, and improvement strategies? Journal of Critical Care, 29(6), 908-914.

Dow, A. W., Zhu, X., Sewell, D., Banas, C. A., Mishra, V., \& Tu, S.-P. (2017). Teamwork on the rocks: Rethinking interprofessional practice as networking. Journal of Interprofessional Care, 31(6), 677-678. doi:10.1080/13561820.2017.1344048

Gausvik, C., Lautar, A., Miller, L., Pallerla, H., \& Schlaudecker, J. (2015). Structured nursing communication on interdisciplinary acute care teams improves perceptions of safety, efficiency, understanding of care plan and teamwork as well as job satisfaction. Journal of 
Multidisciplinary Healthcare, 8, 33-37.

doi: $10.2147 /$ JMDH.S72623

Gums, T. H., Carter, B. L., Milavetz, G., Buys, L., Rosenkrans, K., Uribe, L., . . Wisniewski, A. (2014). Physician-pharmacist collaborative management of asthma in primary care. Pharmacotherapy: The Journal of Human Pharmacology \& Drug Therapy, 34(10), 1033-1042. doi:10.1002/phar.1468

Jesson, J., \& Bissell, P. (2006). Public health and pharmacy: a critical review. Critical Public Health, $16(2), 159-169$.

Jesson, J., \& Lacey, F. (2006). How to do (or not to do) a critical literature review. Pharmacy education, 6.

JointCommission. (2008). Alternatives, Reporting, and Sentinel Event Alert: Behaviors that undermine a culture of safety [Press release]

Katzenbach, J. R., \& Smith, D. K. (1993). The Wisdom of Teams: Creating the High-performance Organization: Harvard Business School Press.

Kelley, H. H., \& Thibaut, J. W. (1978). Interpersonal Relations: A Theory of Interdependence. New York: John Wiley \& Sons.

Khon, L., Corrigan, J., \& Donaldson, M. (2001). Institute of Medicine. Committee on Quality of Health Care in America. To err is human. Building a safer health system: National Academy Press Washington DC.

Korbkitjaroen, M., Vaithayapichet, S., Kachintorn, K., Jintanothaitavorn, D., Wiruchkul, N., \& Thamlikitkul, V. (2011). Effectiveness of comprehensive implementation of individualized bundling infection control measures for prevention of health care-associated infections in general medical wards. American Journal of Infection Control, 39(6), 471-476. doi:10.1016/j.ajic.2010.09.017

Leathard, A. (1994). Going inter-professional: Working together for health and welfare: Psychology Press.

Leathard, A. (2003). Interprofessional Collaboration: From Policy to Practice in Health and Social Care: Brunner-Routledge.

Lisby, M., Thomsen, A., Nielsen, L. P., Lyhne, N. M., Breum-Leer, C., Fredberg, U., . . Brock, B. (2009). The Effect of Systematic Medication Review in Elderly 
Patients Admitted to an Acute Ward of Internal Medicine. Basic \& Clinical Pharmacology \& Toxicology. doi:10.1111/j.1742-7843.2009.00511.x

Manser, T. (2009). Teamwork and patient safety in dynamic domains of healthcare: a review of the literature. Acta Anaesthesiologica Scandinavica, 53(2), 143-151.

Markle-Reid, M., McAiney, C., Forbes, D., Thabane, L., Gibson, M., Browne, G., . . Busing, B. (2014). An interprofessional nurse-led mental health promotion intervention for older home care clients with depressive symptoms. BMC Geriatrics, 14, 62. doi:10.1186/1471-2318$\underline{14-62}$

Miscenko, D., \& Day, D. V. (2016). Identity and identification at work. Organizational Psychology Review, $6(3), 215-247$.

Moore, A., Patterson, C., White, J., House, S. T., Riva, J. J., Nair, K., . . McCann, D. (2012).

Interprofessional and integrated care of the elderly in a family health team. Canadian Family Physician, 58(8), e436-441.

Munneke, M., Nijkrake, M. J., Keus, S. H. J., Kwakkel, G., Berendse, H. W., Roos, R. A. C., . . . Bloem, B. R. (2010). Efficacy of community-based physiotherapy networks for patients with Parkinson's disease: a cluster-randomised trial. The Lancet Neurology, 9(1), 4654. doi:10.1016/S1474-4422(09)70327-8

Muntlin Athlin, A., von Thiele Schwarz, U., \& Farrohknia, N. (2013). Effects of multidisciplinary teamwork on lead times and patient flow in the emergency department: a longitudinal interventional cohort study. Scandinavian Journal of Trauma, Resuscitation and Emergency Medicine, $21(1), 76$. doi:10.1186/1757-7241-21-76

National Quality Board (2016) Supporting NHS providers to deliver the right staff, with the right skills, in the right place at the right time. National Quality Board.

NHS Improving Quality. [online] Retrieved from http://www.nhsiq.nhs.uk/improvement-programmes/long-termconditions-and-integrated-care/mdt-fit-tool.aspx

O'Leary, K. J., Haviley, C., Slade, M. E., Shah, H. M., Lee, J., \& Williams, M. V. (2010). Improving teamwork: Impact of structured interdisciplinary rounds on a hospitalist unit. Journal of Hospital Medicine, 6(2), 8893. doi:10.1002/jhm.714 
O'Leary, K. J., Buck, R., Fligiel, H. M., Haviley, C., Slade, M. E., Landler, M. P., . . Wayne, D. B. (2011). Structured Interdisciplinary Rounds in a Medical Teaching Unit. Archives of Internal Medicine, 171(7). doi:10.1001/archinternmed.2011.128

Page, A. (2004). Keeping patients safe: Transforming the work environment of nurses: National Academies Press.

Paradis, E., Leslie, M., Puntillo, K., Gropper, M., Aboumatar, H. J., Kitto, S., \& Reeves, S. (2014). Delivering interprofessional care in intensive care: a scoping review of ethnographic studies. American Journal of Critical Care, 23(3), 230-238.

Pearce, C. L., \& Herbik, P. A. (2004). Citizenship behavior at the team level of analysis: The effects of team leadership, team commitment, perceived team support, and team size. The Journal of Social Psychology, 144(3), 293-310.

Reeves, S., Goldman, J., Gilbert, J., Tepper, J., Silver, I., Suter, E., \& Zwarenstein, M. (2011). A scoping review to improve conceptual clarity of interprofessional interventions. Journal of Interprofessional Care, 25(3), 167-174.

Reeves, S., Lewin, S., Espin, S., \& Zwarenstein, M. (2010). Interprofessional teamwork for health and social care. Sussex: Wiley-Blackwell.

Reeves, S., Pelone, F., Harrison, R., Goldman, J., \& Zwarenstein, M. (2017). Interprofessional collaboration to improve professional practice and healthcare outcomes. Cochrane Database of Systematic Reviews(6). doi:10.1002/14651858.CD000072.pub3

Rice, K., Zwarenstein, M., Conn, L. G., Kenaszchuk, C., Russell, A., \& Reeves, S. (2010). An intervention to improve interprofessional collaboration and communications: a comparative qualitative study. Journal of Interprofessional Care, 24(4), 350-361.

doi:10.3109/13561820903550713

Saint, S., Fowler, K. E., Krein, S. L., Flanders, S. A., Bodnar, T. W., Young, E., \& Moseley, R. H. (2013). An academic hospitalist model to improve healthcare worker communication and learner education: Results from a quasi-experimental study at a veterans affairs medical center. Journal of Hospital Medicine, 8(12), 702-710. doi:10.1002/jhm.2105 
Salas, E., Cooke, N. J., \& Rosen, M. A. (2008). On teams, teamwork, and team performance: Discoveries and

developments. Human Factors, 50(3), 540-547.

SIGN (2015) SIGN 50: A guideline developers' handbook. Scottish Intercollegiate Guideline Network.

Van Veen-Berkx, E., Bitter, J., Kazemier, G., Scheffer, G. J., \& Gooszen, H. G. (2015). Multidisciplinary teamwork improves use of the operating room: A multicenter study. Journal of the American College of Surgeons, 220(6), 1070-1076. doi:http://dx.doi.org/10.1016/j.jamcollsurg.2015.02.012

Xyrichis, A., \& Ream, E. (2008). Teamwork: a concept analysis. Journal of Advanced Nursing, 61(2), 232-241. 


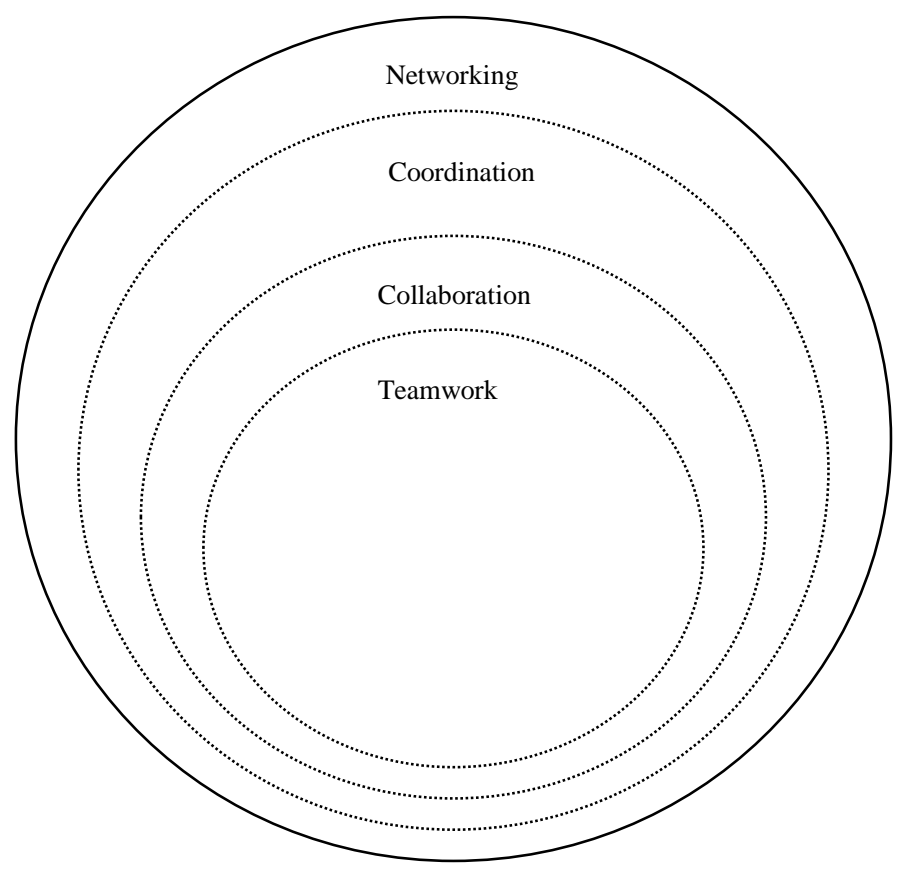

Figure 1: Differing kinds of interprofessional work activity (Reeves et al. 2010) 


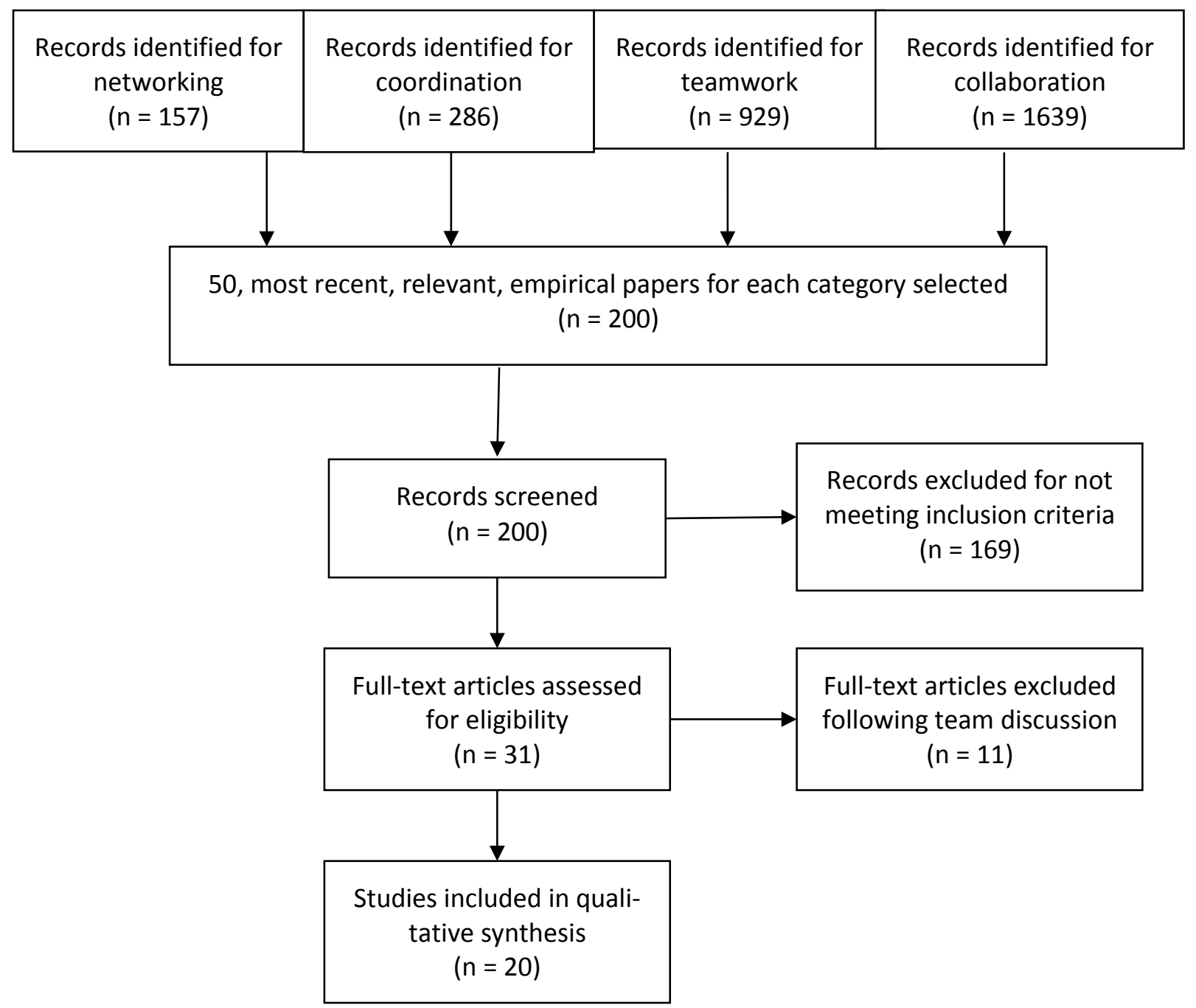

Figure 2: Inclusion and exclusion flowchart 
Table 1: Four kinds of interprofessional activity (Reeves et al. 2010)

\begin{tabular}{|c|c|c|c|}
\hline Teamwork & Collaboration & Coordination & Networking \\
\hline $\begin{array}{l}\text { Teamwork encom- } \\
\text { passes a number } \\
\text { of core ele- } \\
\text { ments includ- } \\
\text { ing, but not } \\
\text { restricted to, } \\
\text { a high level of } \\
\text { shared team } \\
\text { identity, clar- } \\
\text { ity, interde- } \\
\text { pendence, inte- } \\
\text { gration and } \\
\text { shared respon- } \\
\text { sibility. Exam- } \\
\text { ples of this } \\
\text { type of inter- } \\
\text { professional } \\
\text { work can in- } \\
\text { clude family } \\
\text { practice and } \\
\text { emergency de- } \\
\text { partment/room } \\
\text { teams. }\end{array}$ & $\begin{array}{l}\text { Collaboration } \\
\text { is a looser } \\
\text { form of inter- } \\
\text { professional } \\
\text { work. It dif- } \\
\text { fers from team- } \\
\text { work in that } \\
\text { shared identity } \\
\text { and integration } \\
\text { of individuals } \\
\text { are less im- } \\
\text { portant. Howev- } \\
\text { er, it is simi- } \\
\text { lar to teamwork } \\
\text { in requiring } \\
\text { shared account- } \\
\text { ability between } \\
\text { individuals, } \\
\text { some interde- } \\
\text { pendence be- } \\
\text { tween individu- } \\
\text { als and clarity } \\
\text { of roles/goals. } \\
\text { Examples of } \\
\text { this type of } \\
\text { interprofes- } \\
\text { sional work can } \\
\text { be found across } \\
\text { many general } \\
\text { medical set- } \\
\text { tings. }\end{array}$ & $\begin{array}{l}\text { Coordination as } \\
\text { a form of in- } \\
\text { terprofessional } \\
\text { work is similar } \\
\text { to collabora- } \\
\text { tion in terms } \\
\text { of shared iden- } \\
\text { tity. However, } \\
\text { integration and } \\
\text { interdependence } \\
\text { is less im- } \\
\text { portant. Coor- } \\
\text { dination is } \\
\text { similar to col- } \\
\text { laboration in } \\
\text { that it does } \\
\text { require some } \\
\text { shared account- } \\
\text { ability between } \\
\text { individuals and } \\
\text { clarity of } \\
\text { roles/ tasks/ } \\
\text { goals. Examples } \\
\text { of this type of } \\
\text { interprofes- } \\
\text { sional work can } \\
\text { be found in the } \\
\text { case management } \\
\text { literature } \\
\text { which describes } \\
\text { how individu- } \\
\text { als, usually } \\
\text { called case } \\
\text { managers coor- } \\
\text { dinate the work } \\
\text { of the other } \\
\text { team members. }\end{array}$ & $\begin{array}{l}\text { A networking rela- } \\
\text { tionship is one in } \\
\text { which shared team } \\
\text { identity, clarity } \\
\text { of roles/ goals, } \\
\text { interdependence, } \\
\text { integration and } \\
\text { shared responsi- } \\
\text { bility are less } \\
\text { essential. Net- } \\
\text { works can be vir- } \\
\text { tual, in the sense } \\
\text { that none of the } \\
\text { members meet face- } \\
\text { to-face, but com- } \\
\text { municate in an } \\
\text { asynchronous man- } \\
\text { ner by use of the } \\
\text { Internet (e.g. } \\
\text { email or computer } \\
\text { conferencing). Ex- } \\
\text { amples of this } \\
\text { type of interpro- } \\
\text { fessional work in- } \\
\text { clude networks of } \\
\text { clinicians who } \\
\text { meet to discuss or } \\
\text { share infor- } \\
\text { mation/clinical } \\
\text { guidelines across } \\
\text { a number of insti- } \\
\text { tutions. }\end{array}$ \\
\hline
\end{tabular}


Table 2: Database search

1. inter professional.mp.

2. interprofessional.mp.

3. 1 or 2

4. systematic review.pt, sh.

5. (systematic adj (review\$1 or overview\$1)).tw.

6. meta analysis.pt, sh.

7. metaanaly\$.tw.

8. meta analy\$.tw.

9. reference list\$.ab.

10. bibliograph\$.ab.

11. hand-search\$.ab.

12. relevant journals.ab.

13. manual search\$.ab.

14. book.pt, tw, sh.

15. conference.pt, tw, sh.

16. editorial.pt, tw, sh.

17. letter.pt, tw, sh.

18. comment.pt, tw, sh.

19. review.pt, sh.

20. or $/ 4-19$

21. 3 not 20

22. limit 21 to (English language and yr="2005 Current")

23. coordination.mp.

24. co-ordination.mp.

25. or $/ 23-24$

26. 22 and 25

27. networking.mp.

28. 22 and 27

29. collaboration.mp.

30. 22 and 29

31. team work.mp.

32. teamwork.mp.

33. or/31-32

34. 22 and 33 
Table 3: Included papers

\begin{tabular}{|c|c|c|c|}
\hline $\begin{array}{l}\text { Authors } \\
\text { (Year) }\end{array}$ & $\begin{array}{l}\text { Summary } \\
\text { description of } \\
\text { interprofessional } \\
\text { intervention from } \\
\text { the papers }\end{array}$ & $\begin{array}{l}\text { Identified by } \\
\text { authors as: }\end{array}$ & $\begin{array}{l}\text { Classified after } \\
\text { application of } \\
\text { the Reeves et al. } \\
\text { framework as: }\end{array}$ \\
\hline $\begin{array}{l}\text { Auerbach et } \\
\text { al. (2011) }\end{array}$ & $\begin{array}{l}\text { A } \\
\text { multidisciplinary, } \\
\text { unit-based team } \\
\text { serving as the } \\
\text { local agent for } \\
\text { change and safety } \\
\text { awareness by } \\
\text { identifying unit- } \\
\text { based safety } \\
\text { issues and } \\
\text { encouraging team- } \\
\text { based solutions; } \\
\text { meeting twice } \\
\text { monthly. (page } \\
\text { l19) }\end{array}$ & $\begin{array}{l}\text { Teamwork and } \\
\text { communication } \\
\text { programme }\end{array}$ & $\begin{array}{l}\text { Interprofessional } \\
\text { Teamwork }\end{array}$ \\
\hline $\begin{array}{l}\text { Bekelman et } \\
\text { al. (2015) }\end{array}$ & $\begin{array}{l}\text { A collaborative } \\
\text { care team, meeting } \\
\text { weekly, consisting } \\
\text { of a registered } \\
\text { nurse, a primary } \\
\text { care physician, a } \\
\text { cardiologist, and } \\
\text { a psychiatrist; } \\
\text { reviewing patients } \\
\text { and recommending } \\
\text { care. (page } 726 \text { ) }\end{array}$ & $\begin{array}{l}\text { Collaborative } \\
\text { care intervention }\end{array}$ & $\begin{array}{l}\text { Interprofessional } \\
\text { Collaboration }\end{array}$ \\
\hline $\begin{array}{l}\text { Berglund et } \\
\text { al. (2015) }\end{array}$ & $\begin{array}{l}\text { Nurse-led } \\
\text { geriatric } \\
\text { assessment, shared } \\
\text { with a social } \\
\text { worker, } \\
\text { physiotherapist } \\
\text { and/or } \\
\text { occupational } \\
\text { therapist; used to } \\
\text { coordinate } \\
\text { discharge } \\
\text { planning; care- } \\
\text { planning discussed } \\
\text { at an } \\
\text { interprofessional } \\
\text { meeting; followed } \\
\text { up through home } \\
\text { visits. (page } \\
\text { lo8l) }\end{array}$ & $\begin{array}{l}\text { Continuum of care } \\
\text { intervention }\end{array}$ & $\begin{array}{l}\text { Interprofessional } \\
\text { Coordination }\end{array}$ \\
\hline
\end{tabular}




\begin{tabular}{|c|c|c|c|}
\hline $\begin{array}{l}\text { Authors } \\
\text { (Year) }\end{array}$ & $\begin{array}{l}\text { Summary } \\
\text { description of } \\
\text { interprofessional } \\
\text { intervention from } \\
\text { the papers }\end{array}$ & $\begin{array}{l}\text { Identified by } \\
\text { authors as: }\end{array}$ & $\begin{array}{l}\text { Classified after } \\
\text { application of } \\
\text { the Reeves et al. } \\
\text { framework as: }\end{array}$ \\
\hline $\begin{array}{l}\text { Bissonnette } \\
\text { et al. (2013) }\end{array}$ & $\begin{array}{l}\text { A nurse-led clinic } \\
\text { including a } \\
\text { pharmacist, } \\
\text { dietician and } \\
\text { social worker with } \\
\text { a doctor available } \\
\text { for consultation } \\
\text { when needed; } \\
\text { involved weekly } \\
\text { interprofessional } \\
\text { rounds and case } \\
\text { review. (pages } \\
233-234 \text { ) }\end{array}$ & $\begin{array}{l}\text { Collaborative } \\
\text { care approach }\end{array}$ & $\begin{array}{l}\text { Interprofessional } \\
\text { Collaboration }\end{array}$ \\
\hline $\begin{array}{l}\text { Black et al. } \\
(2013)\end{array}$ & $\begin{array}{l}\text { Multifaceted } \\
\text { intervention } \\
\text { involving general } \\
\text { practitioners, } \\
\text { practice managers, } \\
\text { receptionists, } \\
\text { administrators and } \\
\text { nurses; including } \\
\text { the development of } \\
\text { descriptions for } \\
\text { team members' } \\
\text { roles, } \\
\text { responsibilities } \\
\text { and jobs, as well } \\
\text { as meetings for } \\
\text { communication and } \\
\text { care planning. } \\
\text { (pages 186-187) }\end{array}$ & $\begin{array}{l}\text { Team-based } \\
\text { approach }\end{array}$ & $\begin{array}{l}\text { Interprofessional } \\
\text { Collaboration }\end{array}$ \\
\hline $\begin{array}{l}\text { Bunkenborg et } \\
\text { al. (2014) }\end{array}$ & $\begin{array}{l}\text { Physician-led } \\
\text { development of } \\
\text { assessment and } \\
\text { treatment } \\
\text { algorithm for } \\
\text { nurses to use, } \\
\text { report back and } \\
\text { discuss in daily } \\
\text { meetings. (page } \\
425 \text { ) }\end{array}$ & $\begin{array}{l}\text { Interprofessional } \\
\text { communication and } \\
\text { collaboration }\end{array}$ & $\begin{array}{l}\text { Interprofessional } \\
\text { Coordination }\end{array}$ \\
\hline
\end{tabular}




\begin{tabular}{|c|c|c|c|}
\hline $\begin{array}{l}\text { Authors } \\
\text { (Year) }\end{array}$ & $\begin{array}{l}\text { Summary } \\
\text { description of } \\
\text { interprofessional } \\
\text { intervention from } \\
\text { the papers }\end{array}$ & $\begin{array}{l}\text { Identified by } \\
\text { authors as: }\end{array}$ & $\begin{array}{l}\text { Classified after } \\
\text { application of } \\
\text { the Reeves et al. } \\
\text { framework as: }\end{array}$ \\
\hline $\begin{array}{l}\text { Deneckere et } \\
\text { al. (2013) }\end{array}$ & $\begin{array}{l}\text { Development of } \\
\text { care pathways as } \\
\text { an organisational } \\
\text { intervention aimed } \\
\text { to improve } \\
\text { interprofessional } \\
\text { decision-making } \\
\text { and care planning; } \\
\text { involving } \\
\text { surgeons, } \\
\text { physicians, } \\
\text { nurses, } \\
\text { physiotherapists } \\
\text { and social } \\
\text { workers. (page } \\
\text { loo) }\end{array}$ & $\begin{array}{l}\text { Interprofessional } \\
\text { teamwork }\end{array}$ & $\begin{array}{l}\text { Interprofessional } \\
\text { Collaboration }\end{array}$ \\
\hline $\begin{array}{l}\text { Dhalla et al. } \\
(2014)\end{array}$ & $\begin{array}{l}\text { Virtual ward team } \\
\text { consisting of a } \\
\text { care coordinator, } \\
\text { pharmacist, nurse, } \\
\text { physician and a } \\
\text { clerical } \\
\text { assistant; meeting } \\
\text { daily to discuss } \\
\text { cases and develop } \\
\text { individualised } \\
\text { care plans, which } \\
\text { they then } \\
\text { executed. (page } \\
\text { 1306) }\end{array}$ & $\begin{array}{l}\text { Interprofessional } \\
\text { care }\end{array}$ & $\begin{array}{l}\text { Interprofessional } \\
\text { Teamwork }\end{array}$ \\
\hline $\begin{array}{l}\text { Gausvik et } \\
\text { al. (2015) }\end{array}$ & $\begin{array}{l}\text { Interdisciplinary } \\
\text { bedside rounds } \\
\text { with nurses, } \\
\text { geriatricians, } \\
\text { social workers, } \\
\text { physical and } \\
\text { occupational } \\
\text { therapists, } \\
\text { patient care } \\
\text { assistants, } \\
\text { dieticians, speech } \\
\text { and language } \\
\text { therapists; for } \\
\text { case discussion } \\
\text { and treatment } \\
\text { planning. (page } \\
34 \text { ) }\end{array}$ & $\begin{array}{l}\text { Interdisciplinary } \\
\text { care rounds }\end{array}$ & $\begin{array}{l}\text { Interprofessional } \\
\text { Collaboration }\end{array}$ \\
\hline
\end{tabular}




\begin{tabular}{|c|c|c|c|}
\hline $\begin{array}{l}\text { Authors } \\
\text { (Year) }\end{array}$ & $\begin{array}{l}\text { Summary } \\
\text { description of } \\
\text { interprofessional } \\
\text { intervention from } \\
\text { the papers }\end{array}$ & $\begin{array}{l}\text { Identified by } \\
\text { authors as: }\end{array}$ & $\begin{array}{l}\text { Classified after } \\
\text { application of } \\
\text { the Reeves et al. } \\
\text { framework as: }\end{array}$ \\
\hline $\begin{array}{l}\text { Gums et al. } \\
(2014)\end{array}$ & $\begin{array}{l}\text { Collaborative } \\
\text { asthma case } \\
\text { management and } \\
\text { treatment } \\
\text { (medication) } \\
\text { planning involving } \\
\text { physicians and } \\
\text { pharmacists. } \\
\text { Consisted of a } \\
\text { pharmacist } \\
\text { assessment, joint } \\
\text { planning of } \\
\text { treatment goals, } \\
\text { and execution of } \\
\text { these by the } \\
\text { pharmacist. (page } \\
\text { lo36) }\end{array}$ & $\begin{array}{l}\text { Collaborative } \\
\text { management }\end{array}$ & $\begin{array}{l}\text { Interprofessional } \\
\text { Collaboration }\end{array}$ \\
\hline $\begin{array}{l}\text { Korbkitjaroen } \\
\text { et al. (2011) }\end{array}$ & $\begin{array}{l}\text { Team comprising of } \\
\text { a physician and a } \\
\text { nurse, assessing } \\
\text { patients for risk } \\
\text { factors of } \\
\text { infection and } \\
\text { coordinating with } \\
\text { the ward team for } \\
\text { compliance with } \\
\text { infection control } \\
\text { measures. (page } \\
472 \text { ) }\end{array}$ & Team intervention & $\begin{array}{l}\text { Interprofessional } \\
\text { Coordination }\end{array}$ \\
\hline $\begin{array}{l}\text { Lisby et al. } \\
(2009)\end{array}$ & $\begin{array}{l}\text { Clinical } \\
\text { pharmacist and } \\
\text { pharmacologist } \\
\text { reviewing } \\
\text { medication records } \\
\text { and issuing } \\
\text { advisory notes to } \\
\text { primary physicians } \\
\text { with } \\
\text { recommendations } \\
\text { for changes to } \\
\text { prescriptions. } \\
\text { (page 423) }\end{array}$ & $\begin{array}{l}\text { Combined care } \\
\text { intervention }\end{array}$ & $\begin{array}{l}\text { Interprofessional } \\
\text { Coordination }\end{array}$ \\
\hline
\end{tabular}




\begin{tabular}{|c|c|c|c|}
\hline $\begin{array}{l}\text { Authors } \\
\text { (Year) }\end{array}$ & $\begin{array}{l}\text { Summary } \\
\text { description of } \\
\text { interprofessional } \\
\text { intervention from } \\
\text { the papers }\end{array}$ & $\begin{array}{l}\text { Identified by } \\
\text { authors as: }\end{array}$ & $\begin{array}{l}\text { Classified after } \\
\text { application of } \\
\text { the Reeves et al. } \\
\text { framework as: }\end{array}$ \\
\hline $\begin{array}{l}\text { Markle-Reid } \\
\text { et al. (2014) }\end{array}$ & $\begin{array}{l}\text { Nurse-led case } \\
\text { management - } \\
\text { working with an } \\
\text { interprofessional } \\
\text { team of personal } \\
\text { support workers, } \\
\text { home care managers } \\
\text { and physicians - } \\
\text { which included } \\
\text { community } \\
\text { navigation, } \\
\text { facilitating } \\
\text { access to } \\
\text { services, } \\
\text { providing support } \\
\text { across the care } \\
\text { continuum and } \\
\text { coordinating } \\
\text { communication } \\
\text { between the } \\
\text { client, their } \\
\text { family and the } \\
\text { interprofessional } \\
\text { team. (page } 4 \text { ) }\end{array}$ & $\begin{array}{l}\text { Interprofessional } \\
\text { care approach }\end{array}$ & $\begin{array}{l}\text { Interprofessional } \\
\text { Coordination }\end{array}$ \\
\hline $\begin{array}{l}\text { Moore et al. } \\
(2012)\end{array}$ & $\begin{array}{l}\text { A family practice } \\
\text { team consisting of } \\
\text { a nurse } \\
\text { practitioner, } \\
\text { family physician } \\
\text { and registered } \\
\text { practical nurse; } \\
\text { supported by a } \\
\text { pharmacist, social } \\
\text { worker, dietician } \\
\text { and geriatrician. } \\
\text { This involved } \\
\text { patient assessment } \\
\text { and development of } \\
\text { team care plans, } \\
\text { which were } \\
\text { communicated, } \\
\text { shared and } \\
\text { followed up by the } \\
\text { team through } \\
\text { regular case-based } \\
\text { meetings. (page } \\
\text { e437-e438) }\end{array}$ & $\begin{array}{l}\text { Integrated } \\
\text { collaborative } \\
\text { care }\end{array}$ & $\begin{array}{l}\text { Interprofessional } \\
\text { Teamwork }\end{array}$ \\
\hline
\end{tabular}




\begin{tabular}{|c|c|c|c|}
\hline $\begin{array}{l}\text { Authors } \\
\text { (Year) }\end{array}$ & $\begin{array}{l}\text { Summary } \\
\text { description of } \\
\text { interprofessional } \\
\text { intervention from } \\
\text { the papers }\end{array}$ & $\begin{array}{l}\text { Identified by } \\
\text { authors as: }\end{array}$ & $\begin{array}{l}\text { Classified after } \\
\text { application of } \\
\text { the Reeves et al. } \\
\text { framework as: }\end{array}$ \\
\hline $\begin{array}{l}\text { Munneke et } \\
\text { al. }(2010)\end{array}$ & $\begin{array}{l}\text { Network of } \\
\text { physiotherapists } \\
\text { and physicians } \\
\text { working with } \\
\text { people with } \\
\text { Parkinson's' } \\
\text { disease; } \\
\text { facilitating } \\
\text { communication, } \\
\text { information and } \\
\text { knowledge exchange } \\
\text { through joint } \\
\text { seminars, } \\
\text { development of } \\
\text { web-based records } \\
\text { with decision } \\
\text { support, } \\
\text { communication } \\
\text { plans, network } \\
\text { website and } \\
\text { standardised } \\
\text { referral forms. } \\
\text { (page } 48 \text { ) }\end{array}$ & $\begin{array}{l}\text { Community-based } \\
\text { networks }\end{array}$ & $\begin{array}{l}\text { Interprofessional } \\
\text { Networking }\end{array}$ \\
\hline $\begin{array}{l}\text { Muntlin } \\
\text { Athlin et al. } \\
(2013)\end{array}$ & $\begin{array}{l}\text { Reorganisation of } \\
\text { emergency } \\
\text { department work } \\
\text { process, involving } \\
\text { a physician } \\
\text { developing a care } \\
\text { plan, which was } \\
\text { communicated to } \\
\text { and executed by a } \\
\text { nurse supported by } \\
\text { an assistant nurse } \\
\text { with ongoing back- } \\
\text { checking. (page 3) }\end{array}$ & $\begin{array}{l}\text { Multidisciplinary } \\
\text { teamwork }\end{array}$ & $\begin{array}{l}\text { Interprofessional } \\
\text { Coordination }\end{array}$ \\
\hline $\begin{array}{l}\text { o' Leary et }^{\prime} \\
\text { al. }(2011)\end{array}$ & $\begin{array}{l}\text { Weekly rounds } \\
\text { attended by } \\
\text { nurses, } \\
\text { physicians, a } \\
\text { pharmacist, social } \\
\text { worker and case } \\
\text { manager; utilising } \\
\text { a structured } \\
\text { communication tool } \\
\text { to discuss care } \\
\text { planning for newly } \\
\text { admitted patients. } \\
\text { (page 679) }\end{array}$ & $\begin{array}{l}\text { Interdisciplinary } \\
\text { rounds }\end{array}$ & $\begin{array}{l}\text { Interprofessional } \\
\text { Collaboration }\end{array}$ \\
\hline
\end{tabular}




\begin{tabular}{|c|c|c|c|}
\hline $\begin{array}{l}\text { Authors } \\
\text { (Year) }\end{array}$ & $\begin{array}{l}\text { Summary } \\
\text { description of } \\
\text { interprofessional } \\
\text { intervention from } \\
\text { the papers }\end{array}$ & $\begin{array}{l}\text { Identified by } \\
\text { authors as: }\end{array}$ & $\begin{array}{l}\text { Classified after } \\
\text { application of } \\
\text { the Reeves et al. } \\
\text { framework as: }\end{array}$ \\
\hline $\begin{array}{l}\text { Rice et al. } \\
(2010)\end{array}$ & $\begin{array}{l}\text { Ward team of } \\
\text { nurses, nurse } \\
\text { practitioners, } \\
\text { physicians, social } \\
\text { workers, } \\
\text { physiotherapists, } \\
\text { nutritionists, } \\
\text { dieticians, } \\
\text { occupational } \\
\text { therapists, } \\
\text { chaplains and } \\
\text { pharmacists; } \\
\text { adopting a semi- } \\
\text { scripted four-step } \\
\text { communication } \\
\text { process during all } \\
\text { interprofessional } \\
\text { interactions for } \\
\text { making patient } \\
\text { care decisions. } \\
\text { (page 352) }\end{array}$ & $\begin{array}{l}\text { Interprofessional } \\
\text { collaboration }\end{array}$ & $\begin{array}{l}\text { Interprofessional } \\
\text { Collaboration }\end{array}$ \\
\hline $\begin{array}{l}\text { Saint et al. } \\
(2013)\end{array}$ & $\begin{array}{l}\text { Multimodal } \\
\text { intervention } \\
\text { including morning } \\
\text { rounds between } \\
\text { physicians, a } \\
\text { charge nurse, a } \\
\text { pharmacist and a } \\
\text { nurse clinical } \\
\text { care coordinator } \\
\text { whose role was to } \\
\text { facilitate } \\
\text { continuity of } \\
\text { care, } \\
\text { interdisciplinary } \\
\text { communication, } \\
\text { patient discharge, } \\
\text { communication with } \\
\text { an ambulatory care } \\
\text { service for } \\
\text { transition between } \\
\text { inpatient and } \\
\text { outpatient care } \\
\text { and educate } \\
\text { residents and } \\
\text { students on } \\
\text { procedures and } \\
\text { resources. (page } \\
\text { 703-704) }\end{array}$ & $\begin{array}{l}\text { Hospitalist-based } \\
\text { medicine team }\end{array}$ & $\begin{array}{l}\text { Interprofessional } \\
\text { Coordination }\end{array}$ \\
\hline
\end{tabular}




\begin{tabular}{|c|c|c|c|}
\hline $\begin{array}{l}\text { Authors } \\
\text { (Year) }\end{array}$ & $\begin{array}{l}\text { Summary } \\
\text { description of } \\
\text { interprofessional } \\
\text { intervention from } \\
\text { the papers }\end{array}$ & $\begin{array}{l}\text { Identified by } \\
\text { authors as: }\end{array}$ & $\begin{array}{l}\text { Classified after } \\
\text { application of } \\
\text { the Reeves et al. } \\
\text { framework as: }\end{array}$ \\
\hline $\begin{array}{l}\text { Van Veen- } \\
\text { Berkx et al. } \\
(2015)\end{array}$ & $\begin{array}{l}\text { Operating room } \\
\text { (OR) team } \\
\text { consisting of an } \\
\text { anaesthesiologist, } \\
\text { surgeon, } \\
\text { scheduler, or } \\
\text { nurse, anaesthesia } \\
\text { nurse, recovery } \\
\text { room nurse and } \\
\text { ward nurse; } \\
\text { meeting weekly to } \\
\text { review and agree } \\
\text { the OR schedule, } \\
\text { and evaluate OR } \\
\text { performance. (page } \\
\text { lo7l) }\end{array}$ & $\begin{array}{l}\text { Cross-functional } \\
\text { teams }\end{array}$ & $\begin{array}{l}\text { Interprofessional } \\
\text { Teamwork }\end{array}$ \\
\hline
\end{tabular}


Table 4: Revised typology of interprofessional work activities

\begin{tabular}{|c|c|c|c|c|c|c|}
\hline Teamwork & \multicolumn{2}{|l|}{ Collaboration } & \multicolumn{3}{|l|}{ Coordination } & Networking \\
\hline \multirow{2}{*}{$\begin{array}{l}\text { Unchanged } \\
\text { (see } \\
\text { table 1) }\end{array}$} & \multicolumn{2}{|c|}{2 new sub-categories added } & \multicolumn{3}{|c|}{3 new sub-categories added } & \multirow{2}{*}{$\begin{array}{l}\text { Unchanged } \\
\text { (see table } \\
\text { 1) }\end{array}$} \\
\hline & $\begin{array}{l}\text { Consultative } \\
\text { collaboration } \\
\text { A sub-category of } \\
\text { collaboration, } \\
\text { characterised by a } \\
\text { predominantly } \\
\text { consultancy } \\
\text { function from a } \\
\text { collaborative team } \\
\text { to other clinical, } \\
\text { patient or } \\
\text { management groups/ } \\
\text { individuals. }\end{array}$ & $\begin{array}{l}\text { Collaborative } \\
\text { partnership } \\
\text { A sub-category } \\
\text { denoting a } \\
\text { collaborative } \\
\text { type of working } \\
\text { restricted to } \\
\text { just two kinds of } \\
\text { professions, } \\
\text { rather than a } \\
\text { wider } \\
\text { interprofessional } \\
\text { team. }\end{array}$ & $\begin{array}{l}\text { Coordinated } \\
\text { collaboration } \\
\text { Sub-category } \\
\text { denoting a } \\
\text { team with both } \\
\text { a } \\
\text { collaborative } \\
\text { and } \\
\text { coordination } \\
\text { component, of } \\
\text { which the } \\
\text { latter is more } \\
\text { prominent. }\end{array}$ & $\begin{array}{l}\text { Delegative } \\
\text { coordination } \\
\text { Sub-category } \\
\text { of a } \\
\text { coordinated } \\
\text { team } \\
\text { involving a } \\
\text { large } \\
\text { component of } \\
\text { delegation in } \\
\text { its decisions } \\
\text { or actions. }\end{array}$ & $\begin{array}{l}\text { Consultative } \\
\text { coordination } \\
\text { Sub-category of } \\
\text { coordination in } \\
\text { which the team } \\
\text { performs a } \\
\text { predominantly } \\
\text { consultative } \\
\text { function to } \\
\text { other } \\
\text { clinicians or } \\
\text { management } \\
\text { groups. }\end{array}$ & \\
\hline
\end{tabular}


Table 5: InterProfessional Activity Classification Tool (InterPACT)

\begin{tabular}{|c|c|c|c|c|c|c|}
\hline $\begin{array}{l}\text { Dimensions of } \\
\text { Kinds of } \\
\text { IP activity }\end{array}$ & $\begin{array}{l}\text { Shared } \\
\text { commitment }\end{array}$ & $\begin{array}{l}\text { Shared } \\
\text { identity }\end{array}$ & $\begin{array}{l}\text { Clear team } \\
\text { goals }\end{array}$ & $\begin{array}{l}\text { Clear roles and } \\
\text { responsibilities }\end{array}$ & $\begin{array}{l}\text { Interdependence } \\
\text { between team } \\
\text { members }\end{array}$ & $\begin{array}{l}\text { Integration } \\
\text { between work } \\
\text { practices }\end{array}$ \\
\hline Teamwork & $\oplus \oplus \oplus \oplus$ & $\oplus \oplus \oplus \oplus$ & $\oplus \oplus \oplus \oplus$ & $\oplus \oplus \oplus \oplus$ & $\oplus \oplus \oplus \oplus$ & $\oplus \oplus \oplus \oplus$ \\
\hline Collaboration & $\oplus \oplus \oplus \oplus$ & $\oplus \oplus \oplus$ & $\oplus \oplus \oplus$ & $\oplus \oplus \oplus$ & $\oplus \oplus \oplus$ & $\oplus \oplus \oplus$ \\
\hline $\begin{array}{l}\text { Consultative } \\
\text { collaboration }\end{array}$ & $\oplus \oplus \oplus \oplus$ & $\oplus \oplus \oplus$ & $\oplus \oplus \oplus$ & $\oplus \oplus \oplus$ & $\oplus \oplus$ & $\oplus \oplus$ \\
\hline $\begin{array}{l}\text { Collaborative } \\
\text { partnership }\end{array}$ & $\oplus \oplus \oplus \oplus$ & $\oplus \oplus \oplus$ & $\oplus \oplus \oplus$ & $\oplus \oplus \oplus$ & $\oplus$ & $\oplus \oplus$ \\
\hline Coordination & $\oplus \oplus \oplus$ & $\oplus \oplus \oplus$ & $\oplus \oplus \oplus$ & $\oplus \oplus$ & $\oplus \oplus$ & $\oplus \oplus$ \\
\hline $\begin{array}{l}\text { Coordinated } \\
\text { collaboration }\end{array}$ & $\oplus \oplus \oplus$ & $\oplus \oplus \oplus$ & $\oplus \oplus \oplus$ & $\oplus \oplus$ & $\oplus$ & $\oplus$ \\
\hline $\begin{array}{l}\text { Delegative } \\
\text { coordination }\end{array}$ & $\oplus \oplus$ & $\oplus \oplus$ & $\oplus \oplus \oplus$ & $\oplus \oplus$ & $\oplus$ & $\oplus$ \\
\hline $\begin{array}{l}\text { Consultative } \\
\text { coordination }\end{array}$ & $\oplus \oplus$ & $\oplus \oplus$ & $\oplus \oplus \oplus$ & $\oplus \oplus$ & - & $\oplus$ \\
\hline Networking & $\oplus \oplus$ & $\oplus \oplus$ & $\oplus \oplus$ & $\oplus$ & $\oplus$ & $\oplus$ \\
\hline
\end{tabular}

Intensity expected: $\oplus_{\text {Low }} \oplus \oplus_{\text {Moderate; }} \oplus \oplus_{\text {High }} ; \oplus \oplus \oplus \oplus_{\text {Very high }}$ 
